\title{
Vaginal Papillary Carcinoma
}

National Cancer Institute

\section{Source}

National Cancer Institute. Vaginal Papillary Carcinoma. NCI Thesaurus. Code C128060.

A rare squamous cell carcinoma that arises from the vagina resembling transitional cell carcinoma of the urinary tract. 